Ambiente \& Água - An Interdisciplinary Journal of Applied Science
ISSN 1980-993X - doi:10.4136/1980-993X
www.ambi-agua.net
E-mail: ambi.agua@gmail.com

\title{
Sewage sludge compost in zoysia grass sod production
}

\author{
ARTICLES doi:10.4136/ambi-agua.2301
}

Received: 19 Jul. 2018; Accepted: 01 Dec. 2018

\author{
Flávia Diniz Mota*iD; Roberto Lyra Villas Bôas ${ }^{(D}$; \\ Caroline de Moura D’Andréa Mateus $D^{\circledR}$; Tatiane Bortoletto Gomes da Silva \\ Universidade Estadual Paulista (UNESP), Botucatu, SP, Brasil \\ Faculdade de Ciências Agronômicas (FCA). Departamento de Solos e Recursos Ambientais. \\ E-mail: fdmota@yahoo.com.br, rlvboas@fca.unesp.br, caroline_mateus@hotmail.com, \\ tatibortoletto@live.com \\ *Corresponding author
}

\begin{abstract}
This study evaluated whether the use of composted sewage sludge in zoysia grass sod production can partially or completely substitute fertilization based on urea. The experiment was conducted on a sod farm located in Itapetininga, São Paulo State, Brazil. The experimental design was a complete randomized block design with five replications and experimental plots of $5 \mathrm{~m}^{2}$ in a $2 \times 6$ factorial scheme. The first factor was the method of application (single or split), and the second factor was composted sewage sludge fertilization and two controls (no fertilization and a standard dose of conventional fertilizer). The conventional fertilizer (urea) dose corresponds to $300 \mathrm{~kg} \mathrm{~N} \mathrm{ha}^{-1}$ and the sewage compost doses correspond to 100, 200, 300, and $400 \mathrm{~kg} \mathrm{~N} \mathrm{ha}^{-1}$. The experiment began with the liming of the total area at 60 days after the previous harvest of zoysia grass sod. Three methods were used to evaluate sod production: soil cover rate, green color intensity, and leaf analysis. At 212 days after the beginning of the experiment, the compost treatment of $30 \mathrm{Mg} \mathrm{ha}^{-1}\left(300 \mathrm{~kg} \mathrm{ha}^{-1}\right.$ of $\left.\mathrm{N}\right)$, applied in a single dose, allowed for complete sod formation (100\% soil cover rate).
\end{abstract}

Keywords: nitrogen, organic fertilization, soil cover rate, SPAD, turfgrass.

\section{Lodo de esgoto compostado na produção de grama esmeralda}

\section{RESUMO}

Objetivou-se com este trabalho avaliar se o uso de lodo de esgoto compostado na produção de grama esmeralda pode substituir parcial ou totalmente a adubação com uréia. O experimento foi conduzido em área de produção de grama, localizada em Itapetininga-SP. O delineamento experimental utilizado foi de blocos ao acaso, com cinco repetições e parcelas experimentais de $5 \mathrm{~m}^{2}$ em esquema fatorial $2 \times 6$, sendo o primeiro fator a forma de aplicação, parcelada e não parcelada e o segundo fator a adubação com lodo de esgoto compostado e duas testemunhas (sem adubação e dose usual de adubação inorgânica). A dose de adubo inorgânico foi correspondente a $300 \mathrm{~kg} \mathrm{~N} \mathrm{ha}^{-1}$ e as doses de lodo de esgoto compostado foram correspondentes a 100, 200, 300 e $400 \mathrm{~kg} \mathrm{~N} \mathrm{ha}^{-1}$. O início do experimento ocorreu 60 dias após a colheita dos tapetes de grama esmeralda, com a realização de calagem em área total. Foram utilizados três métodos para avaliar a produção do tapete de grama esmeralda: taxa de cobertura do solo, intensidade de cor verde e análise foliar. Aos 212 dias após o início do experimento, a adubação 
orgânica com lodo de esgoto compostado, na dose de $30 \mathrm{Mg} \mathrm{ha}^{-1}$ (300 $\mathrm{kg} \mathrm{ha}^{-1} \mathrm{de} \mathrm{N}$ ), aplicado de forma não parcelada, permitiu formação do tapete de grama (100\% taxa de cobertura do solo).

Palavras-chave: adubação orgânica, grama, nitrogênio, SPAD, taxa de cobertura do solo.

\section{INTRODUCTION}

The use of in natura or composted sewage sludge as a soil conditioner and source of nutrients for agricultural crops is an alternative disposal method for such waste that is used in several countries (Singh and Agrawal, 2008; Corradi et al., 2016). In Brazil, its use is regulated by Conama Resolution 375 (Conama, 2006), which limits the levels of acceptable pathogenicity for Class A sludge, thus making direct use of sewage sludge in agriculture unviable. However, it is legally possible to compost the sludge by mixing it with a carbon source to produce a Class D Compound Organic Fertilizer Product, according to the Ministry of Agriculture (MAPA) Federal Decree 4.954 of January 14, 2004 and Normative Instructions 23 from 08/31/2005 and 27 from 05/06/2006.

The composting process not only transforms the biodegradable material into humus, but also reduces and deactivates pathogens and reduces the concentration of heavy metals, thus making it adequate for use as a fertilizer to provide nutrients to the soil (Kiehl, 1985; Paredes Filho, 2011; Rashad et al., 2010).

The use of composted sewage sludge in the production of sod grass has previously been analyzed. For example, Angle et al. (1981) showed improvements related to quality, postharvest survival, and the production system for Kentucky bluegrass (Poa pratensis L.). Other studies corroborate these results (Schnell et al., 2009; Tesfamariam et al., 2009; Griffith et al., 2017).

Zoysia grass (Zoysia japonica) is the main species of grass cultivated in Brazil, and it currently covers approximately $80 \%$ of the total production area (Grama Legal National Association, 2017). The species is usually cultivated for use in landscaping projects, sports fields and along highways due to its resistance to drought and trampling, rapid rooting, and its adaptability to a tropical climate (Turfgrass Producers International, 2002; Gurgel, 2003).

Because of its stoloniferous-rhizomatous growth habit, zoysia grass shows high resistance to trampling and an elevated rate of soil cover. According to Li et al. (2011), rhizomes and stolons linked to nitrogen fertilization are responsible for the resistance and quality of the sod.

Nitrogen $(\mathrm{N})$ is the most important nutrient in the production of zoysia grass sod and is directly associated with shoot growth, increased green coloration, resistance, and soil cover rate. Although $\mathrm{N}$ demand varies with soil type, previous studies have shown that the best responses occur with $408 \mathrm{~kg} \mathrm{~N} \mathrm{ha}^{-1}$ per year for zoysia grass (Godoy et al., 2007) and $425 \mathrm{~kg}$ $\mathrm{N} \mathrm{ha}^{-1}$ per year for Kentucky bluegrass (Griffith et al., 2017).

Composted sewage sludge can present a $\mathrm{N}$ concentration of $10 \mathrm{~g} \mathrm{~kg}^{-1}$ based on dry matter. As such, it has the potential to fully satisfy the demand for this nutrient without the need for synthetic fertilizers and minerals (Singh and Agrawal, 2008; 2009; Mehrotra et al., 2016) in the production of zoysia grass sod. In addition to being rich in $\mathrm{N}$, and because it presents stabilized organic matter, organic compost has a direct impact on the physical and biological properties of the soil, since part of the applied biosolids will remain in the soil after the sod harvest (Schnell et al., 2009; De Maria et al., 2007).

In this context, this study aims to verify the effects of fertilization with composted sewage sludge on zoysia grass production, with the goal of partially or completely replacing the use of urea fertilization. Thus, herein we test four doses of this organic fertilizer. 


\section{MATERIALS AND METHODS}

The experiment was performed from April 2015 to December 2015, in a zoysia grass sod

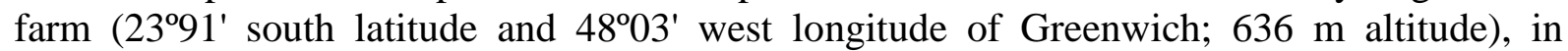
Itapetininga, São Paulo State, Brazil. The soil in the area is classified as Red Dystrophic Latosol (EMBRAPA, 2006) and the climate is classified as Cfa (subtropical) based on the KöppenGeiger System (Peel et al. 2007), with cold, dry winters, and hot, humid summers (Cunha and Martins, 2009).

We used a randomized block experimental design with five replications and experimental plots of $5 \mathrm{~m}^{2}$ in a 2x6 factorial scheme, with the first factor including two different methods of application (single or split application), and the second factor being type of fertilization treatment (Figure 1).

\begin{tabular}{|c|c|c|}
\hline \multirow[b]{2}{*}{31} & \multicolumn{2}{|c|}{ Block A } \\
\hline & $\mathrm{d} 3 \mathrm{a} 2$ & $\mathrm{~d} 3 \mathrm{a} 1$ \\
\hline 32 & d6a2 & $\mathrm{d} 2 \mathrm{a} 2$ \\
\hline 33 & $\mathrm{~d} 4 \mathrm{a} 2$ & dla2 \\
\hline 34 & d6al & dlal \\
\hline 35 & $\mathrm{~d} 5 \mathrm{al}$ & $\mathrm{d} 4 \mathrm{a} 1$ \\
\hline 36 & $\mathrm{~d} 5 \mathrm{a} 2$ & $\mathrm{~d} 2 \mathrm{a} 1$ \\
\hline
\end{tabular}

\begin{tabular}{|c|c|c|}
\hline \multirow[b]{2}{*}{19} & \multicolumn{2}{|c|}{ Block B } \\
\hline & dlal & dla2 \\
\hline 20 & $\mathrm{~d} 2 \mathrm{a} 1$ & $\mathrm{~d} 2 \mathrm{a} 2$ \\
\hline 21 & d3al & $\mathrm{d} 3 \mathrm{a} 2$ \\
\hline 22 & $\mathrm{~d} 4 \mathrm{a} \mathrm{l}$ & $\mathrm{d} 4 \mathrm{a} 2$ \\
\hline 23 & d5al & $\mathrm{d} 5 \mathrm{a} 2$ \\
\hline 24 & d6al & d6a2 \\
\hline
\end{tabular}

\begin{tabular}{|c|c|c|}
\hline \multirow[b]{2}{*}{7} & \multicolumn{2}{|c|}{ Block C } \\
\hline & dla2 & $\mathrm{d} 6 \mathrm{a} 2$ \\
\hline 8 & d6al & $\mathrm{d} 5 \mathrm{a} 2$ \\
\hline 9 & $\mathrm{~d} 2 \mathrm{a} 2$ & $\mathrm{~d} 5 \mathrm{al}$ \\
\hline 10 & $\mathrm{~d} 4 \mathrm{a} 2$ & $\mathrm{~d} 3 \mathrm{a} 2$ \\
\hline 11 & $\mathrm{~d} 2 \mathrm{a} 1$ & d3al \\
\hline 12 & $\mathrm{~d} 4 \mathrm{a} 1$ & dlal \\
\hline
\end{tabular}

$\mathrm{d}=$ Dose

\begin{tabular}{|c|c|c|}
\hline \multirow[b]{2}{*}{43} & \multicolumn{2}{|c|}{ Block D } \\
\hline & $\mathrm{d} 2 \mathrm{a} 2$ & $\mathrm{~d} 4 \mathrm{a} 2$ \\
\hline 44 & $\mathrm{~d} 6 \mathrm{a} 2$ & $\mathrm{~d} 3 \mathrm{a} 2$ \\
\hline 45 & $\mathrm{~d} 1 \mathrm{a} 2$ & $\mathrm{~d} 4 \mathrm{al}$ \\
\hline 46 & $\mathrm{~d} 5 \mathrm{a} 2$ & dlal \\
\hline 47 & d3al & $\mathrm{d} 5 \mathrm{al}$ \\
\hline 48 & d6al & $\mathrm{d} 2 \mathrm{al}$ \\
\hline
\end{tabular}

\begin{tabular}{|c|c|c|}
\hline \multirow[b]{2}{*}{55} & \multicolumn{2}{|c|}{ Block E } \\
\hline & $\mathrm{d} 4 \mathrm{a} 2$ & d6al \\
\hline 56 & $\mathrm{~d} 2 \mathrm{a} 2$ & $\mathrm{~d} 3 \mathrm{a} 2$ \\
\hline 57 & $\mathrm{~d} 5 \mathrm{a} 2$ & dlal \\
\hline 58 & dla2 & $\mathrm{d} 2 \mathrm{al}$ \\
\hline 59 & d5al & $\mathrm{d} 4 \mathrm{al}$ \\
\hline 60 & d6a2 & d3al \\
\hline
\end{tabular}

$\mathrm{a}=$ Application

Figure 1. Graphical schema of experiment.

To assess the effects of fertilization on zoysia grass sod production, the treatments included: urea; sewage sludge compost (SSC) in four different doses $\left(10,20,30\right.$ and $40 \mathrm{tha}^{-1}$ of compost sewage sludge, dry weight), based on the requirement of $\mathrm{N}(100,200,300$ and 400 $\mathrm{kg} \mathrm{N} \mathrm{ha}^{-1}$ ); and a control (no fertilizer). Four treatments received a single application of the SCC fertilizer and the other treatments included two applications: 50\% of the SSC at the beginning of the experiment and a second application after reaching a soil cover rate of $50 \%$. The sewage sludge compost came from the sewage treatment facility in Jundiaí, São Paulo State (Table 1). 
Table 1. Chemical composition of the sewage sludge compost.

\begin{tabular}{lc}
\hline Parameter & Concentration $^{(1)}$ \\
\hline Nitrogen $\left(\mathrm{g} \mathrm{kg}^{-1}\right)$ & 10.7 \\
Phosphorus $\left(\mathrm{g} \mathrm{kg}^{-1}\right)$ & 6 \\
Organic Carbon $\left(\mathrm{g} \mathrm{kg}^{-1}\right)$ & 165 \\
Potassium $\left(\mathrm{mg} \mathrm{kg}^{-1}\right)$ & 8452 \\
Total Solids $(\%)$ & 69.8 \\
Volatile Compounds (\%) & 30.0 \\
$\mathrm{pH}$ & 8.6 \\
Humidity (\%) & 27.2 \\
Cation Exchange Capacity $\left(\mathrm{mmol}_{\mathrm{c}} \mathrm{kg}^{-1}\right)$ & 314 \\
C:N Ratio & 15 \\
\hline (1) Except for humidity, results are expressed based on dry \\
weight.
\end{tabular}

Liming of the total area was conducted by applying $1.2 \mathrm{t} \mathrm{ha}^{-1}$ of dolomitic limestone (PRNT 95\%) and was based on the soil base saturation of the experimental area. At 60 days after the previous turfgrass sod harvest, the single application fertilization was applied. The first application of the split application was also applied at that time with the second application occurring at 127 days after the first, when the soil cover rate (SCR) reached 50\%. In the plots treated with urea, a dose of $300 \mathrm{~kg} \mathrm{~N} \mathrm{ha}^{-1}$ was given in a single application, corresponding to $670 \mathrm{~kg} \mathrm{ha}^{-1}$, at 25 days after the beginning of the experiment.

Three methods were used to evaluate zoysia grass sod production: soil cover rate (SCR), green color intensity (GCI), and leaf nitrogen content analysis.

Soil cover rate (SCR) was assessed through a digital image. The images were taken parallel to the lawn surface with a 3.0-megapixel digital camera coupled to a lightbox, similar to that described in Peterson et al. (2011), which standardizes the lighting and the image area. Subsequently, images were analyzed in Sigma Scan software and the SCR percentage was obtained by counting green pixels.

Green color intensity (GCI) was obtained using the non-destructive absorbance method in a portable Chlorophyll Meter, Soil and Plant Analysis Development (SPAD) Model 502 (Minolta Co., Osaka, Japan). Leaves were collected from each plot, placed in plastic bags, and stored in a Styrofoam box with ice for transportation to the laboratory. Shortly after arrival at the laboratory, the leaves were hydrated and a reading taken for each leaf, with 30 leaves analyzed per plot, to obtain an average value per treatment. SCR and GCI were measured at 45, 93, 127, and 156 days after application (DAA) of sewage sludge compost.

For the analysis of leaf nitrogen content, grass was cut in the plots and the shavings were ground and sent to the Plant Nutrition Laboratory in the Soils and Environmental Resources Department/Unesp, following a modified methodology based on Malavolta et al. (1997). Analyses were performed at 93 and 156 DAA of sewage sludge compost.

Data were submitted to analysis of variance and regression methods. Nitrogen dose effects were compared using Tukey's test, with $p=0.05$. Statistical analyses were performed using the software Minitab16.

\section{RESULTS AND DISCUSSION}

Soil cover rate (SCR) of zoysia grass showed significant interaction between dose and application at only 45 and 156 DAA of composted sludge $(p<0.05)$ (Table 2). According to Godoy (2007), soil cover rate is the first indicator in the formation of turfgrass sod. 
Table 2. Means and summary of analysis of variance of soil cover rate (SCR) (n=5).

\begin{tabular}{|c|c|c|c|c|c|c|c|c|}
\hline \multicolumn{9}{|c|}{ Soil Cover Rate (\%) } \\
\hline Doses of SSC & \multicolumn{2}{|c|}{45 DAA } & \multicolumn{2}{|c|}{93 DAA } & \multicolumn{2}{|c|}{127 DAA } & \multicolumn{2}{|c|}{156 DAA } \\
\hline $\mathrm{Mg} \mathrm{ha}^{-1}$ & \multicolumn{8}{|c|}{ Application } \\
\hline & 1 & 2 & 1 & 2 & 1 & 2 & 1 & 2 \\
\hline 0 & $18.5 b$ & $19.0 \mathrm{a}$ & 27.9 & 35.6 & 56.6 & 62.8 & $60.9 \mathrm{Abc}$ & $49.7 \mathrm{Bb}$ \\
\hline 10 & $24.6 \mathrm{~b}$ & $20.0 \mathrm{a}$ & 32.9 & 37.3 & 61.5 & 60.3 & $59.3 b c$ & $55.6 \mathrm{~b}$ \\
\hline 20 & $27.2 b$ & $22.2 \mathrm{a}$ & 30.9 & 29.3 & 65.1 & 62.8 & 75.0Aab & 64.2Bab \\
\hline 30 & $31.8 \mathrm{~b}$ & $22.2 \mathrm{a}$ & 30.1 & 26.6 & 66.9 & 58.7 & 82.4Aa & 63.0Bab \\
\hline 40 & 48.7Aa & $22.5 \mathrm{Ba}$ & 39.6 & 31.1 & 66.7 & 62.4 & $90.0 \mathrm{Aa}$ & $72.0 \mathrm{Ba}$ \\
\hline \multirow[t]{2}{*}{ Urea } & $18.3 b$ & & 36.8 & & 68.9 & & $68.7 \mathrm{c}$ & \\
\hline & & & & & & $\mathrm{p}$ & & \\
\hline Dose (D) & \multicolumn{2}{|c|}{0.0001} & \multicolumn{2}{|c|}{0.547} & \multicolumn{2}{|c|}{0.841} & \multicolumn{2}{|c|}{0.0001} \\
\hline Application (A) & \multicolumn{2}{|c|}{0.0001} & \multicolumn{2}{|c|}{0.953} & \multicolumn{2}{|c|}{0.248} & \multicolumn{2}{|c|}{0.0001} \\
\hline $\mathrm{D} \times \mathrm{A}$ & \multicolumn{2}{|c|}{0.001} & \multicolumn{2}{|c|}{0.713} & \multicolumn{2}{|c|}{0.721} & \multicolumn{2}{|c|}{0.032} \\
\hline C.V (\%) & \multicolumn{2}{|c|}{29.00} & \multicolumn{2}{|c|}{36.7} & \multicolumn{2}{|c|}{25.45} & \multicolumn{2}{|c|}{5.58} \\
\hline
\end{tabular}

Means followed by the same lowercase letters in the column and uppercase letters in the rows do not differ statistically based on a Tukey test.

1 - Single application; 2 - Split application.

Splitting the composted sludge into two applications showed no advantage compared to the single application at all sampling times for SCR. An explanation for this effect arises from the fact that a greater mass of organic matter in the soil retains a greater volume of water, especially during periods without rain. Another factor that may have contributed to this result is the period required for decomposition of the second portion of the sludge compound applied in November. The amount of time may not have been sufficient to release all nutrients. According to the nutrient evaluation conducted by Backes et al. (2013), 67\% of the $\mathrm{N}$ is released within a period of up to 120 days. Meanwhile, Godoy et al. (2007) note the need for basic fertilization for shoot development to begin.

The largest applied dose $\left(40 \mathrm{Mg} \mathrm{ha}^{-1}\right)$ provided a maximum coverage rate (SCR 100\%) at 212 DAA. Backes et al. (2009), in their study to verify non-composted sewage sludge doses in zoysia grass sod production, found that a single application of $40 \mathrm{Mg} \mathrm{ha}^{-1}$ produced the maximum coverage rate at 165 DAA. Meanwhile, in a different study, Backes et al. (2013) evaluated the effects of composted sewage sludge on the production of zoysiagrass and found that a dose of $46.8 \mathrm{Mg} \mathrm{ha}^{-1}$ produced the maximum SCR only at 380 DAA. These results suggest that the addition of a carbon source during the sewage sludge composting process dilutes the nutrients in the sludge, thus requiring a higher dose to reach the maximum SCR.

Plots that received syntetic fertilization (SF) showed a SCR of approximately $21 \%, 12 \%$, $10 \%$ and $29 \%$ lower in comparison to the highest dose of applied sludge. Backes et al. (2013), comparing a dose of $48 \mathrm{Mg} \mathrm{ha}^{-1}$ of sludge with a control (no fertilization), showed a lower SCR by $61 \%$ and $65 \%$ at 45 and 130 DAA, respectively.

At 127 DAA, treatments with SF provided an SCR 2.2\% greater than the highest dose of applied SSC, and at 156 DAA the highest SSC dose showed a $20 \%$ increase over IF (Figure 2). This result can be directly related to the effect of soil moisture, which favors the decomposition of organic matter and slows the release of nutrients with the application of the SSC in comparison to urea. 


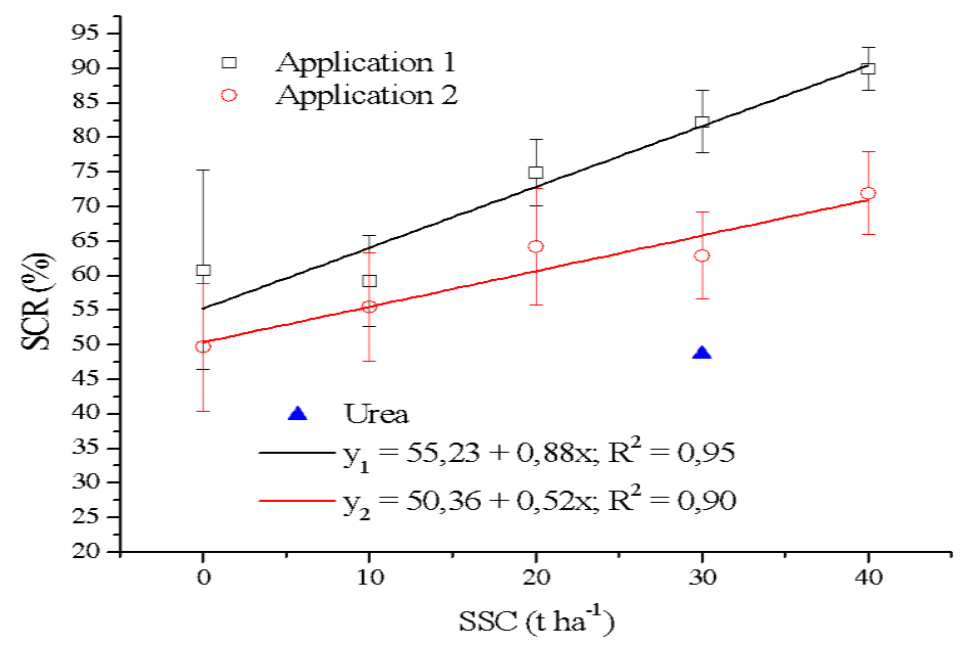

Figure 2. Soil Cover Rate (SCR) for zoysia grass as a function of the sewage sludge compost doses, urea, and methods of application, at 156 days after application (DAA) of sludge compost.

Green color intensity (GCI), represented by the SPAD value, is directly related to the concentration of chlorophyll in the leaves, representing a higher production of carbohydrates and quick rooting of the sod after planting (Christians, 1998). The doses of composted sewage sludge and the two methods of application significantly influenced the GCI at 45 and 93 days after application. At 127 DAA of composted sewage sludge, a significant effect was observed only for the applied doses (Table 3).

Table 3. Means and summary of analysis of variance of green color intensity (GCI) (n=5).

\begin{tabular}{|c|c|c|c|c|c|c|c|c|c|c|}
\hline \multicolumn{11}{|c|}{ Green Color Intensity (SPAD) } \\
\hline & \multicolumn{2}{|c|}{45 DAA } & \multicolumn{3}{|c|}{93 DAA } & \multicolumn{3}{|c|}{127 DAA } & \multicolumn{2}{|c|}{156 DAA } \\
\hline Doses of SSC & \multicolumn{10}{|c|}{ Application } \\
\hline $\mathrm{Mg} \mathrm{ha}^{-1}$ & 1 & 2 & 1 & 2 & Mean & 1 & 2 & Mean & 1 & 2 \\
\hline 0 & $27.9 \mathrm{Ac}$ & $27.0 \mathrm{Aa}$ & 26.9 & 27.4 & $27.1 \mathrm{~b}$ & 26.5 & 26.1 & $26.3 \mathrm{~b}$ & 27.8 & 27.2 \\
\hline 10 & $30.4 \mathrm{Abc}$ & $28.7 \mathrm{Aa}$ & 28.4 & 29.3 & $28.8 \mathrm{ab}$ & 27.6 & 25.9 & $26.7 \mathrm{ab}$ & 26.6 & 25.6 \\
\hline 20 & $31.6 \mathrm{Abc}$ & $28.7 \mathrm{Aa}$ & 28.6 & 27.4 & $28.0 \mathrm{ab}$ & 27.8 & 26.9 & $27.3 \mathrm{ab}$ & 26.8 & 26.7 \\
\hline 30 & 35.0 Aab & $30.7 \mathrm{Aa}$ & 31.5 & 29.2 & $30.3 \mathrm{a}$ & 29.0 & 29.2 & $29.1 \mathrm{ab}$ & 27.7 & 27.1 \\
\hline 40 & $37.0 \mathrm{Aa}$ & $30.5 \mathrm{Ba}$ & 32.4 & 28.8 & $30.6 \mathrm{a}$ & 31.7 & 26.9 & $29.3 \mathrm{a}$ & 29.5 & 28.6 \\
\hline Mean & & & $29.5^{\mathrm{a}}$ & 28.4B & & 28.5 & 27.0 & & & \\
\hline Urea & $27.6 \mathrm{Ac}$ & - & 28.8 & - & 28.8 Aab & 26.4 & - & $26.4 \mathrm{ab}$ & 25.5 & - \\
\hline \multicolumn{11}{|c|}{$\mathrm{p}$} \\
\hline Dose (D) & \multicolumn{2}{|c|}{0.0001} & \multicolumn{3}{|c|}{0.004} & \multicolumn{3}{|c|}{0.016} & \multicolumn{2}{|c|}{0.320} \\
\hline Application (A) & \multirow{2}{*}{\multicolumn{2}{|c|}{$\begin{array}{c}0.0001 \\
0.007\end{array}$}} & \multirow{2}{*}{\multicolumn{3}{|c|}{$\begin{array}{l}0.026 \\
0.221\end{array}$}} & \multicolumn{3}{|c|}{0.071} & \multicolumn{2}{|c|}{0.820} \\
\hline D x A & & & & & & \multicolumn{3}{|c|}{0.119} & \multicolumn{2}{|c|}{0.914} \\
\hline C.V (\%) & \multicolumn{2}{|c|}{. } & \multicolumn{3}{|c|}{7.85} & \multicolumn{3}{|c|}{8.37} & \multicolumn{2}{|c|}{11.23} \\
\hline
\end{tabular}

Means followed by the same lowercase letters in the column and uppercase letters in the rows do not differ statistically based on Tukey test.

1 - Single application; 2 - Split application. 
At 45 DAA, GCI can be expressed as a linear model that increases with an increase in the applied sludge dose: $\left(\mathrm{y}_{1}=27.83+0.23 \mathrm{x}, \mathrm{r}^{2}=0.99\right)$ and $\left(\mathrm{y}_{2}=27.14+0.09 \mathrm{x}, \mathrm{r}^{2}=0.90\right)$, split application and single application, respectively.

We also found that GCI at 45 days after application was greater in relation to the other evaluated time periods, due to a greater release of $\mathrm{N}$ until that date, corroborating the results found by Backes et al. (2010). At 45 DAA, we observed green color indices ranging from 27.9 to 37 SPAD units, which supports the concept that beginning from a $\mathrm{N}$ deficiency situation there is a linear response of GCI with increasing doses (Fig. 2), related to increasing chlorophyll content of the grass (Carvalho et al., 2003). Unlike the results observed for SCR, we found statistical differences between the treatments for doses and application method, with the highest values (35 and 37 SPAD) obtained with a single application of SSC for doses of 30 and $40 \mathrm{Mg}$ $\mathrm{ha}^{-1}$, as shown in Table 3. As the GCI is correlated with levels of N, we can infer that with an applied dose of $30 \mathrm{Mg} \mathrm{ha}^{-1}$, the zoysia grass reached the maximum value of $\mathrm{N}$, and this may indicate an optimal dose for this parameter.

The assessment at 156 DAA did not present statistically different results; however, it was possible to observe differences in soil cover (SCR, presented in Table 2) and, consequently, plant mass. This fact could have generated a uniformity in GCI results, since treatments with a greater dose of composted sludge showed increased plant growth. As such, $\mathrm{N}$ was diluted in the aerial part of the plant, which caused a decrease in concentration in comparison with the control or lower doses of SSC. Beard (1973) observed the effect of dilution on chlorophyll concentration when very high doses of $\mathrm{N}$ were used, leading to a reduced GCI.

GCI varied throughout the experiment, ranging from 27 to 37 SPAD. Our findings indicate that zoysia grass that received high doses of $\mathrm{N}$ achieved a GCI greater than 37 SPAD units at 90, 192, and 296 days after cutting (DAC). However, when no N was applied, the GCI ranged from 22.9 to 28.9 at 124,192 , and 296 DAC.

Our data suggest a significant interaction between dose and application for mean $\mathrm{N}$ leaf concentration at 93 and 156 days after application (Table 4).

Table 4. Means and summary of analysis of variance of foliar leaf $\mathrm{N}$ concentration $(\mathrm{n}=5)$.

\begin{tabular}{lcccc}
\hline \multicolumn{5}{c}{ Foliar leaf N concentration $\left(\mathrm{g} \mathrm{kg}^{-1}\right)$} \\
\hline \multicolumn{5}{c}{$93 \mathrm{DAA}$} \\
\hline Doses of SSC & \multicolumn{5}{c}{ Application } \\
\cline { 2 - 5 } $\mathrm{Mg} \mathrm{ha}^{-1}$ & $156 \mathrm{DAA}$ \\
\hline 0 & $10.39 \mathrm{c}$ & 10.85 & 13.89 & 12.93 \\
10 & $12.19 \mathrm{bc}$ & 11.86 & 12.64 & 10.22 \\
20 & $13.64 \mathrm{bc}$ & 11.52 & 14.74 & 12.74 \\
30 & $14.71 \mathrm{Ab}$ & $11.21 \mathrm{~B}$ & 12.74 & 10.13 \\
40 & $18.95 \mathrm{Aa}$ & $12.81 \mathrm{~B}$ & 15.03 & 11.72 \\
\hline Urea & $10.21 \mathrm{c}$ & - & 11.68 \\
\hline \multicolumn{5}{c}{$\mathrm{p}$} \\
\hline Dose (D) & \multicolumn{5}{c}{-} \\
Application (A) & 0.001 & 0.505 \\
D x A & 0.001 & 0.058 \\
\hline C.V (\%) & 0.001 & 0.937 \\
\hline
\end{tabular}

Means followed by the same lowercase letters in the column and uppercase letters in the rows do not differ statistically based on Tukey test.

1 - Single application; 2 - Split application. 
We observed a linear increase in the $\mathrm{N}$ concentration in leaf blades $(\mathrm{y}=9.59+0.23 \mathrm{x}$, $\left.\mathrm{R}^{2}=0.97\right)$, reaching a maximum value of $18.95 \mathrm{~g} \mathrm{~kg}^{-1}$ at 93 DAA with a single dose treatment of $40 \mathrm{Mg} \mathrm{ha}^{-1}$ composted sewage sludge (Table 4). Experiments performed in the field and in greenhouses, with the application of in natura and composted sewage sludge, also showed a linear increase in nitrogen concentration in leaf blades (Backes et al., 2010; Tester, 1989).

The maximum value found for $\mathrm{N}$ is slightly below the ideal range of 20 to $24 \mathrm{~g} \mathrm{~kg}^{-1}$, as suggested by Mills and Jones (1996). Backes et al. (2010), studying the effects of in natura sewage sludge, found a $\mathrm{N}$ concentration of $28 \mathrm{~g} \mathrm{~kg}^{-1}$ at 105 DAA.

At $156 \mathrm{DAA}$, with the dose of $40 \mathrm{Mg} \mathrm{ha}^{-1}$, we found a $\mathrm{N}$ concentration in the leaf blade of $15.03 \mathrm{~g} \mathrm{~kg}^{-1}$, which provided the highest SCR of 90\%. At 105 DAA, Backes et al. (2009) found that a foliar leaf $\mathrm{N}$ concentration of $17 \mathrm{~g} \mathrm{~kg}^{-1}$ provided more than $95 \%$ of SCR and at 165 DAA the concentration range was from 19 to $22 \mathrm{~g} \mathrm{~kg}^{-1}$.

From the results, we can infer that, due to the dilution effect, there is a tendency toward a decrease in the nutrient concentration in the leaf throughout the cycle, where a redistribution of $\mathrm{N}$ occurs with an increase in the total plant mass. The management of the lawn including the trimming and removal of cuttings, and the consequent removal of nutrients, also explains the reduction in concentration of $\mathrm{N}$ at $156 \mathrm{DAA}$. For this study, a dose of $30 \mathrm{Mg} \mathrm{ha}^{-1}$ can be considered optimum, since the increase in SPAD value of approximately 5\% does not justify increasing the dose to $40 \mathrm{Mg} \mathrm{ha}^{-1}$, considering the costs of production.

\section{CONCLUSIONS}

A $30 \mathrm{Mg} \mathrm{ha}^{-1}$ dose of sewage sludge compost is the most suitable for sod production.

A divided application of sewage sludge compost is not recommended.

Sewage sludge compost used in the production of zoysia grass had beneficial effects and the use of SSC in zoysia grass sod production can substitute urea fertilization.

\section{ACKNOWLEDGEMENTS}

This study was supported by the Coordination for the Improvement of Higher Education Personnel (CAPES, Brazil). We would also like to thank the company Tera Ambiental for financing the project.

\section{REFERENCES}

ANGLE, J. S.; WOLF, D. C.; HALL, J. R. Turfgrass growth aided by sludge compost. BioCycle, v. 22, p. 40-43, 1981.

BACKES, C.; SANTOS, A. J. M.; GODOY, L. J. G.; VILLAS BÔAS, R. L.; OLIVEIRA, M. R.; OLIVEIRA, F. C. Doses de lodo de esgoto compostado em produção de tapete de grama esmeralda imperial. Revista Brasileira de Ciência do Solo, v. 37, n. 5, p. 14021414, 2013. http://dx.doi.org/10.1590/S0100-06832013000500029

BACKES, C.; BÔAS, V.; LYRA, R.; LIMA, C. P. D.; GODOY, L. J. G. D.; BÜLL, L. T. et al. Leaf nitrogen nutritional status of zoysia grass evaluated by nitrogen concentration, chlorophyll meter and digital image, in sewage sludge fertilized areas. Bragantia, v. 69, n. 3, p. 661-668, 2010. http://dx.doi.org/10.1590/S0006-87052010000300018

BACKES, C.; BULL, L.T.; GODOY, L. J. G.; VILLAS BÔAS, R. L.; LIMA, C. P.; PIRES, E. C. Uso de lodo de esgoto na produção de tapetes de grama esmeralda. Ciência Rural, v. 39, p. 1045-1050, 2009. http://dx.doi.org/10.1590/S0103-84782009000400014 
BEARD, J. B. Turfgrass: science and culture. Englewood Cliffs: Prentice-Hall, 1973. 235 p.

CARVAlHO, M. A. C. de; FURLANI JUNIOR, E.; ARF, O.; SÁ, M. E.; PAULINO, H. B.; BUZETTI, S. Doses e épocas de aplicação de nitrogênio e teores foliares deste nutriente e de clorofila em feijoeiro. Revista Brasileira de Ciência do Solo, v. 27, p. 445-450, 2003. https://doi.org/10.1590/S0100-06832003000300006

CHRISTIANS, N. E. Fundamental of turfgrass management. Chelsea: Arbor Press, 1998. $301 \mathrm{p}$.

CONSELHO NACIONAL DO MEIO AMBIENTE - CONAMA (Brasil). Resolução n. 375, de 29 de agosto de 2006. Diário Oficial [da] União, seção 1, 30 agosto 2006.

CORRADI, I. C.; DE MATOS, A. T.; DE MATOS, M. P.; BORGES, A. C.; AQUINO, J. M. G. L. Degradação do lodo de esgoto sanitário compostado quando disposto no solo. Engenharia Agrícola, v. 36, n. 5, 2016.

CUNHA, A. R.; MARTINS, D. Classificação climática para os municípios de Botucatu e São $\begin{array}{llllllll}\text { Manuel, SP. Irriga, } & \text { v. } 14, \quad \text { n. } & 1, & \text { p. } & 1-11,\end{array}$ https://doi.org/10.15809/irriga.2009v14n1p1-11

DE MARIA, I. C.; KOCSSI, M. A.; DECHEN, S. C. F. Agregação do solo em área que recebeu lodo de Esgoto. Bragantia, v. 66, n. 2, p. 291-298, 2007.

EMBRAPA. Centro Nacional de Pesquisa de Solos-CNPS. Sistema brasileiro de classificação de solos. Brasília: Embrapa-SPI; Rio de Janeiro: Embrapa-CNPS, 2006. 306 p.

GODOY, L. J. G. et al. Doses de nitrogênio e potássio na produção de grama esmeralda. Ciência e Agrotecnologia, v. 31, n. 5, p. 1326-1332, 2007.

GRAMA LEGAL NATIONAL ASSOCIATION. Produção de grama. 2017. Available in: http//www.gramalegal.com. Access: March 10, 2018.

GRIFFITH, S.; BERO, N.; STIER, J.; OBEAR, G.; RUIS, S.; SOLDAT, D. Biosolids as an Alternative Fertilizer for Kentucky Bluegrass Sod Production in Wisconsin. Crop $\begin{array}{llllll}\text { Science, } & \text { v. } & 57, & \text { Suppl1, } & \text { p. } & \text { S-227-S-237, }\end{array}$ http://dx.doi.org/10.2135/cropsci2016.05.0367

GURGEL, R. A. G. Principais espécies e variedades de grama. In: SIMPOSIO SOBRE GRAMADOS, 1., 2003, Botucatu. Produção, implantação e manutenção: anais[...] Botucatu: UNESP, Faculdade de Ciências Agronômicas, 2003.

KIEHL, E. J. Fertilizantes orgânicos. Piracicaba: Ceres,1985. 492 p.

LI, D.; FANG, W.; HAN, L. Nitrogen fertilization influences shear strength and quality of Kentucky bluegrass sod grown on clay. Agronomy Journal, v. 103, p. 751-755, 2011. http://dx.doi.org/10.2134/agronj2010.0470

MALAVOLTA, E.; VITTI, G. C.; OLIVEIRA, S. A. Avaliação do estado nutricional das plantas: princípios e aplicações. 2. ed. Piracicaba: POTAFOS, 1997. 317p.

MEHROTRA, A.; KUNDU, K.; SREEKRISHNAN, T. R. Decontamination of heavy metal laden sewage sludge with simultaneous solids reduction using thermophilic sulfur and ferrous oxidizing species. Journal of Environmental Management, v. 167, p. 228-235, 2016. https://doi.org/10.1016/j.jenvman.2015.11.004 
MILLS, H. A.; JONES, J. B. Jr. Plant analysis handbook II: a practical sampling, preparation, analysis and interpretation guide. Athens: MicroMacro, 1996. $456 \mathrm{p}$.

PAREDES FILHO, M. V. Compostagem de lodo de esgoto para uso agrícola. Revista Agroambiental, v. 3, n. 3, p.73-80, 2011.

PETERSON, K.; SHONKWILER ARNOLD, K.; BREMER, D. Custom Light Box for Digital Image Turfgrass Analysis. K- State Turfgrass Research Report of Progress 1035, p. 89-91, 2011.

RASHAD, F. M.; SALEH, W. D.; MOSELHY, M. A. Bioconversion of rice straw and certain agro-industrial wastes to amendments for organic farming systems: 1. Composting, quality, stability and maturity indices. Bioresource Technology, v. 101, n. 15, p. 59525960, 2010. https://doi.org/10.1016/j.biortech.2010.02.103

SCHNELL, R.W.; VIETOR, D. M.; WHITE, R. H.; PROVIN, T. L.; MUNSTER, C. L. Effects of composted biosolids and nitrogen on turfgrass establishment, sod properties, and nutrient export at harvest. HortScience, v. 44, p. 1746 -1750, 2009.

SINGH, R. P.; AGRAWAL, M. Potential benefits and risks of land application of sewage $\begin{array}{llllll}\text { sludge. Waste } & \text { Management, v. 28, p. 347-358, } 2008 .\end{array}$ https://doi.org/10.1016/j.wasman.2006.12.010

SINGH, R. P.; AGRAWAL, M. Use of sewage sludge as fertilizer supplement for Abelmoschus esculentus plants: physiological, biochemical and growth responses. International Journal of Environment and Waste Management, v. 3, p. 91-106, 2009.

TESFAMARIAM, T. H.; ANNANDALE, J. G.; STEYN, J. M.; STIRZAKER, M. J. Exporting large volumes of municipal sewage sludge through turfgrass sod production. Journal of $\begin{array}{llllll}\text { Environmental Quality, } & \text { v. } & 38, & \text { p. }\end{array}$ http://dx.di.org/10.2134/jeq2008.0397

TESTER, C. F. Tall fescue growth in greenhouse, growth chamber, and field plots amended with sludge compost and fertilizer. Soil Science, v. 148, p. 452-458, 1989.

TURFGRASS PRODUCERS INTERNATIONAL. Turfgrass: functional, recreational e aesthetic. Turf Resource Center, 2002. Available in: http//www.turfgrass sod.org/trc/statistics.html. Access: March 10, 2018. 